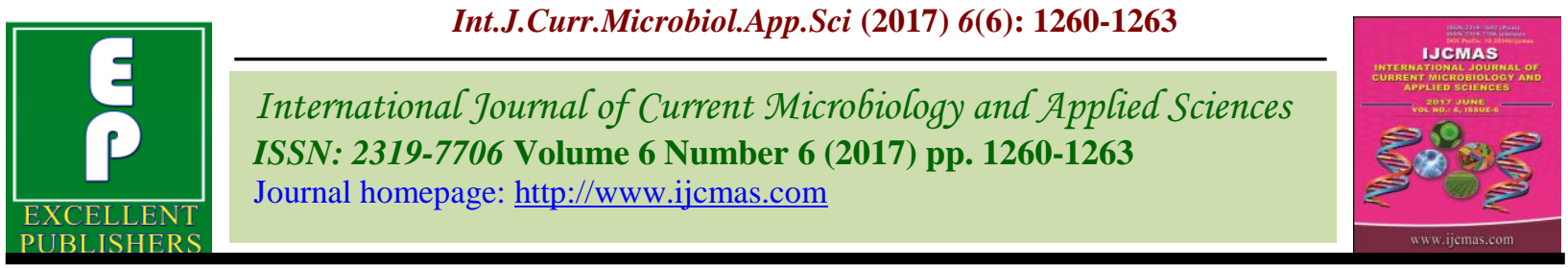

Original Research Article

https://doi.org/10.20546/ijcmas.2017.606.147

\title{
Gender Disaggregated Roles for Feeding of Dairy Animals in Manipur, India
}

\author{
Abul K. Azad*, Sanjeev Kuma and Chandan K. Rai \\ Dairy Extension Division, ICAR-NDRI, Karnal-132001, India \\ *Corresponding author
}

A B S T R A C T

It believed that the domestication of animals and crops was done by the women in the ancient age, thereby initiated the art and science of farming. In the present context, rural women folk are extensively involved in agricultural and allied activities, their work has been increased from home to land and vice-versa. However the nature and extent of their

Keywords

Feeding, Gender roles, Dairy animals, Common Property Resources.

Article Info

Accepted:

19 May 2017

Available Online:

10 June 2017 involvement differs in different geographic location. Therefore in order to explore the gender involvement in various feeding practices for dairy animals, the study was conducted in two district of Manipur i.e. Imphal East and Imphal West. The total 160 respondents (Men and Women) were selected from eight villages for investigation. The men and women were separately interviewed. The data was collected enthusiastically followed by analysis and interpretation. The analysis was done by using of appropriate statistical tools. After successful analysis it was found that the practices related to fodder cultivation such as purchasing of seeds, sowing of seeds, giving irrigation, weeding of fodder crops etc. we're not doing vigorously. The result shows that the majority of the male $(77.50 \%)$ engaged in gathering of fodders from the fields. Purchase of Concentrate $(21.25 \%)$, preparation of feed mixture $(48.75 \%)$, feeding of pregnant animals $(11.25 \%)$, harvesting of fodder crops $(2.50 \%)$ were done by the women respectively. Overall observation was that the farmers in the region were not interested in commercial dairy farming, so the cultivation of fodder crops is a questionable. Those who are rearing dairy animals, their major source of green fodder is from the forest, common property resources. Lastly, it is highly recommended that the dairy sector has good future in the region, but foremost things to bring interest of the people towards milk \& milk products is the major challenge.

\section{Introduction}

Livestock and people of India has great affection to each other which evidences by various research scholars. This affection between them uses as a tool for upbringing the economic condition of the country. In recent times, the livestock sector in India has been growing faster than crop sector. Presently the total milk production of India is 153 million tonnes and it happened due to the effort of dairy farmers by adjusting breeding, feeding, healthcare and management (Vsion
-2050). Livestock play a significant role in uplifting the poor and small farmers, it becomes one of the means which provides employment to the rural man, women and youth.

The rearing of cattle for milk production is not a child play which undergoes various activities and it is evidences that the most of the milk production states in India such as Uttar Pradesh, Punjab, Haryana, Rajasthan 
etc. where the dairy farm related activities are performed by women robustly.

According to the Census of India (2001), there are nearly 12 million cultivators, 107.5 million agricultural labourers and 6 million other farm workers engaged in livestock, forestry and plantations, out of the total agricultural labourers, 38.0 per cent were female and 61.9 percent, male workers (Anonymous, 2001). In Bangladesh, among the 10.3 million women labour forces, the share of rural women is 7.6 million compared with the 2.6 million urban labour forces (Bangladesh Basic Statistics, 2006). The world scenario speak that the women are involved in all aspects of agriculture and allied enterprise from land preparation to processing and marketing, apart from the bulk of the household subsistence work which includes food preparation, health care, and, the acquisition and stewardship of natural resources. Above information are clearly tells that the contribution of women in agriculture and livestock labour significantly welldefined but it has been found that the women roles are inadequately recognized or documented. In this context, the study was carried out for further highlighting the "gender disaggregated roles for feeding of dairy animals in Manipur". As in the state, the women are highly empowered in activities, so, it generated interested for us to know the utilization of empowerment towards dairy sector in the selected area.

\section{Materials and Methods}

The study was conducted in Imphal East and Imphal West district of Manipur, a small North Eastern State of India. Eight villages were selected randomly and from each village ten farm families, thus total farm families were 80 and respondents 160 respectively. The men and women were interviewed separately with the of help semi-structured interview schedule to get the clear picture regarding gender disaggregated role for feeding of dairy animals.

\section{Results and Discussion}

The study was purposively focus on the feeding roles played by the male, female and jointly during the investigation. For this investigation 13 statements were taken and interviewed separately.

Table 1 revealed that purchasing seed of fodder crops $(3.75 \%)$, sowing of fodder seed $(3.75 \%)$, and irrigation of fodder crops $(2.50$ $\%)$ were done by male and $(1.25 \%)$ female counterparts. The jointly participation of purchasing seed of fodder crops, sowing of fodder seed and irrigation of fodder crops were $(1.83 \%)$ respectively. As the North Eastern Region are lacking behind in terms of commercial dairy farming, that's why the people are not growing fodders for their animals. Whatever little work related animal husbandry was done participated by the male counterpart only.

Table 1 depicted that $(100.00 \%)$ no weeding of fodder crops was done by both male and female, as they are not bother about the green fodder losses. For them growing of weeds in the field is value addition. It was also found that only $(2.50 \%)$ of the male respondents were applied fertilizer to the fodder crops and remaining $(97.50 \%)$ respondents were not. Harvesting of fodder crops were done by $(2.50 \%)$ female, $(1.25 \%)$ male and jointly $(1.83 \%)$. As a general point of view in the state, the tribal female has active participation in terms of crop harvesting which is passing by generation to generation.

If we talk about NER, it is covered with forest where the abundant green fodders are available, so $(77.50 \%)$ male and (10.00\%) female were involved in gathering of fodders. 
Chaffing of fodder was done by male $(18.75 \%)$, female $(12.50 \%)$ followed by jointly $(15.62 \%)$. Most of the farmers fed their animals directly because chaffing is time consuming. When they used to prepare homemade concentrate i.e. rice bran + salt+ kitchen waste+ local grass that time only they chopped otherwise not. It has been observed that the farmers were not concerned about digestibility and palatability of green fodder intake by the animals, similar kind of information also revealed by Chayal et al., 2009.

Table.1 Feeding roles played by respondents

\begin{tabular}{|c|c|c|c|c|}
\hline $\begin{array}{l}\text { Sl. } \\
\text { no }\end{array}$ & Roles & $\begin{array}{c}\text { Male } \\
(\mathbf{n}=80)\end{array}$ & $\begin{array}{c}\text { Female } \\
(\mathbf{n}=80)\end{array}$ & $\begin{array}{c}\text { Jointly } \\
(n=160)\end{array}$ \\
\hline 1 & $\begin{array}{l}\text { Purchasing of seed of fodder } \\
\text { crops }\end{array}$ & $\begin{array}{c}3 \\
(3.75 \%)\end{array}$ & 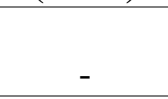 & $\begin{array}{c}3 \\
(1.87 \%)\end{array}$ \\
\hline 2 & Sowing of seeds of fodder crops & $\begin{array}{c}3 \\
(3.75 \%)\end{array}$ & - & $\begin{array}{c}3 \\
(1.87 \%)\end{array}$ \\
\hline 3 & Irrigation to fodder crops & $\begin{array}{c}2 \\
(2.50 \%)\end{array}$ & $\begin{array}{c}1 \\
(1.25 \%)\end{array}$ & $\begin{array}{c}3 \\
(1.87 \%)\end{array}$ \\
\hline 4 & Weeding of fodder crops & & & \\
\hline 5 & Applying fertilizer to fodder crops & $2(2.50 \%)$ & - & $2(1.25 \%)$ \\
\hline 6 & Harvesting of fodder crops & $\begin{array}{c}1 \\
(1.25 \%)\end{array}$ & $\begin{array}{c}2 \\
(2.50 \%)\end{array}$ & $\begin{array}{c}3 \\
(1.87 \%)\end{array}$ \\
\hline 7 & Gathering of fodder crops & $\begin{array}{c}62 \\
(77.50 \%)\end{array}$ & $\begin{array}{c}8 \\
(10.00 \%)\end{array}$ & $\begin{array}{c}70 \\
(43.75 \%)\end{array}$ \\
\hline 8 & Chaffing & $\begin{array}{c}15 \\
(18.75 \%)\end{array}$ & $\begin{array}{c}10 \\
(12.50 \%)\end{array}$ & $\begin{array}{c}25 \\
(15.62 \%)\end{array}$ \\
\hline 9 & Feeding management of calf & $\begin{array}{c}46 \\
(57.50 \%) \\
\end{array}$ & $\begin{array}{c}13 \\
(16.25 \%)\end{array}$ & $\begin{array}{c}59 \\
(36.87 \%) \\
\end{array}$ \\
\hline 10 & Feeding of pregnant animal & $\begin{array}{c}41 \\
(51.25 \%) \\
\end{array}$ & $\begin{array}{c}9 \\
(11.25 \%)\end{array}$ & $\begin{array}{c}50 \\
(31.25 \%) \\
\end{array}$ \\
\hline 11 & Purchase of green and dry fodder & $\begin{array}{c}6 \\
(7.50 \%)\end{array}$ & $\begin{array}{c}5 \\
(6.25 \%)\end{array}$ & $\begin{array}{c}11 \\
(6.87 \%)\end{array}$ \\
\hline 12 & Purchase of concentrate & $\begin{array}{c}17 \\
(21.25 \%)\end{array}$ & - & $\begin{array}{c}17 \\
(10.62 \%)\end{array}$ \\
\hline 13 & Preparation of feed mixture & $\begin{array}{c}39 \\
(48.75 \%)\end{array}$ & $\begin{array}{c}7 \\
(8.75 \%)\end{array}$ & $\begin{array}{c}46 \\
(28.75 \%)\end{array}$ \\
\hline
\end{tabular}

Other parameters more or less also depicting the similar kind of situation in the study area, table 1 clearly showed that feeding management of calf $(57.50 \%)$, feeding of pregnant animals $(51.25 \%)$, purchase of green and dry fodder $(7.50 \%)$, purchase of concentrate $(21.25 \%)$ and preparation of feed mixture $(48.75 \%)$ were done by male, likewise feeding management of calf $(16.25 \%)$, feeding of pregnant animal (11.25\%), purchase of green and dry fodder
$(6.25 \%)$ and preparation of feed mixture $(8.75 \%)$ were done by female respondents. Jointly engaged in feeding management of calf $(36.87 \%)$, feeding of pregnant animals $(31.25 \%)$, purchase of green and dry fodder (6.87\%), purchase of concentrate $(10.62 \%)$ and preparation of feed mixture $(28.75 \%)$ respectively were found. It can be clearly concluded that most of the feeding related activities are done by the male farmers and female has less access to it. Another aspects is 
that the concentration has significant role in overall growth and performance of animals where it is witnessed that the supplying of readymade concentrate and mineral mixture were limited once or twice in a year in case of local cattle but as per crossbred animal is concerned they are little bit conscious due higher milk production and productivity.

The livestock sector is one of the principal components of GDP and service providing sector. The revenue from milk production has maximum contribution to the livestock sector. Unfortunately there is a regional imbalance where the north eastern states contributes very small of percent of milk production due to the various socio-cultural factors. The region is highly dominant with tribal and their major food habits were non-vegetarian which is the main reason to have less interest in commercial milk and milk products production, apart from all the pros and cons, the region have limited access to this sector, moreover the percentage of access to dairy related activities performing in the study area were done by male counterparts.

\section{References}

Anonymous. 2001. Population Census of India.

Bangladesh Basic Statistics. 2006.

Chayal, K., B.L. Daaka and R.L. Suwalka. 2009. Analysis of role performed by farm women in dairy farming. Indian $J$. Dairy Sci., 62(6): 491-494.

Vsion-2050. Indian Veterinary Research Institute, Uttar Pradesh.

\section{How to cite this article:}

Abul K. Azad, Sanjeev Kuma and Chandan K. Rai. 2017. Gender Disaggregated Roles for Feeding of Dairy Animals in Manipur, India. Int.J.Curr.Microbiol.App.Sci. 6(6): 1260-1263. doi: https://doi.org/10.20546/ijcmas.2017.606.147 